\title{
Inleiding op het thema 'Psychische vermoeidheid in de arbeidssituatie'**
}

\author{
Wilmar Schaufeli* \& Irene Houtman*
}

In 1996 ging het zogenoemde NWO-PRIORITEIT-programma 'Psychische vermoeidheid in de arbeidssituatie' (PVA) van start, dat in 2004 officieel wordt beëindigd met een slotcongres, waar dit themanummer zal worden uitgereikt. De destijds door NWO in het leven geroepen, en inmiddels overigens weer afgeschafte, PRIORITEIT-programma's waren bedoeld om multidisciplinair wetenschappelijk onderzoek met een duidelijke maatschappelijke meerwaarde te stimuleren. Het beleid van NWO was er destijds op gericht om niet alleen zuiver wetenschappelijk onderzoek te bevorderen, maar ook toegepast onderzoek dat expliciet bijdraagt aan het oplossen van maatschappelijke problemen. Eén van de meest dringende problemen was het aantal mensen dat tijdelijk /via de Ziektewet) of nagenoeg permanent (via de WAO) uit het arbeidsproces viel vanwege psychische klachten, waarvan vermoeidheid een kernsymptoom vormt. Midden jaren negentig van de vorige eeuw waren psychische klachten verantwoordelijk voor ruim $40 \%$ van het arbeidsgebonden ziekteverzuim en bijna $30 \%$ van de WAO-instroom (Houtman, 1997). Hiermee was destijds een bedrag van ruim $€ 2,2$ miljard gemoeid. Een recente herberekening over 2001 laat zien dat inmiddels $43 \%$ van de kosten van arbeidsuitval (ziekteverzuim en WAO) voor rekening van psychische aandoeningen komt. Dit komt neer op ruim $€ 5$ miljard, en is $1,2 \%$ van het bruto binnenlands product (Koningsveld, Zwinkels, Mossink, Thie \& Abspoel, 2004). Kortom, werkgerelateerde psychische klachten zijn nog steeds een groot maatschappelijke probleem dat nu al bijna twee decennia in het middelpunt van de politieke belangstelling staat. Een wetenschappelijk onderzoeksprogramma dat pretendeert deze problematiek in kaart te brengen en oplossingen aan te dragen was - en is - dan ook meer dan welkom.

Het doel van het NWO-PVA-programma is het entameren en stimuleren van een reeks samenhangende onderzoeken vanuit bedrijfsgezondheidskundige, epidemiologische, fysiologische en psychologische invalshoeken naar psychische vermoeidheid in de arbeidssituatie. Het gaat daarbij om het ontstaan, de signalering en de preventie van vermoeidheid in de arbeidssituatie; de gevolgen ervan voor het functioneren binnen en buiten de arbeid; en de gevolgen ervan voor ziekte en gezondheid. Het onderzoeksprogramma heeft twee belangrijke kenmerken. Ten eerste is het programma multidisciplinair van opzet. Tot aan de

\footnotetext{
* De auteurs vormen de redactiecommissie van dit thema. Wilmar Schaufeli is hoogleraar Organisatiepsychologie en Klinische Psychologie aan de Universiteit Utrecht. Irene Houtman is senior-onderzoeker bij TNO Arbeid.

**Aan dit themanummer hebben behalve de auteurs van de diverse artikelen, die ook als beoordelaars van elkaars conceptartikelen zijn opgetreden, ook een drietal 'externe' beoordelaars meegewerkt. Onze dank gaat daarbij uit naar Harriëtte Riese, Jan Fekke Ybema en Steven Dhondt.
} 
start van het NWO-PVA-programma was het vermoeidheidsonderzoek voornamelijk monodisciplinair van karakter. Het vond plaats in de arbeidspsychologie, de klinische psychologie, de epidemiologie, de fysiologie, de verzekeringsgeneeskunde en de bedrijfsgezondheidskunde. Dit leverde weliswaar belangrijke deelresultaten op, maar de grenzen van de desbetreffende disciplines werden nauwelijks overschreden en er was praktisch geen sprake van gezamenlijke onderzoeksinspanningen. Naast het genereren van specifieke, multidisciplinaire kennis omtrent psychische vermoeidheid in de arbeidssituatie beoogt het NWO-PVA-programma - ten tweede - bij te dragen aan de toepassing van deze inzichten en daarmee aan de wetenschappelijke ondersteuning van de Arbopraktijk. De Arbowet vraagt een actieve opstelling van werkgevers en werknemers ten aanzien van preventie van gezondheids- en welzijnsrisico's. Voorts kent deze wet aan arbodiensten een belangrijke rol toe, namelijk de professionele ondersteuning en advisering hierbij. De benodigde inzichten en instrumenten hiertoe ontbreken echter grotendeels. Samenvattend: het gaat bij het NWO-PVAprogramma dus om een multidisciplinair onderzoeksprogramma waarbij theorie en (arbo)praktijk nauw op elkaar zijn aangesloten. Dat het NWO-PVA-programma over een groot maatschappelijk draagvlak beschikt blijkt uit het feit dat bijna de helft van het totale budget van $€ 5,5$ miljoen is opgebracht door bedrijven, vakbonden, arbodiensten, en onderzoeks- en adviesinstellingen.

Wat is nu precies psychische vermoeidheid in de arbeidssituatie? Onder psychische vermoeidheid wordt het verschijnsel verstaan dat het gevolg is van psychische belasting, die zich heeft ontwikkeld tijdens voorafgaande arbeidsactiviteit, en betrekking heeft op negatieve veranderingen in psychische functies op basis waarvan het moeilijk, of zelfs onmogelijk wordt om doelgericht taakgedrag te ontwikkelen of in stand te houden (Meijman \& Schaufeli, 1996). Het is van belang om een onderscheid te maken tussen acute vermoeidheid en chronische vermoeidheid die zich als psychische klacht voordoet. Acute vermoeidheid is een normaal verschijnsel dat optreedt nadat men een tijdlang gewerkt heeft; het is taakspecifiek en reversibel op korte termijn. Dat wil zeggen, de vermoeidheid verdwijnt grotendeels wanneer men overschakelt op een andere activiteit en men kan er gemakkelijk van herstellen door rust te nemen. Chronische vermoeidheid daarentegen is veel minder taakspecifiek en op kortere termijn nauwelijks reversibel. Overspannen werknemers worden bijvoorbeeld ook moe wanneer ze de krant lezen en hun vermoeidheid neemt niet af na een nachtje goed geslapen te hebben. Kortom, het gaat bij psychische vermoeidheid dus niet om een bepaalde entiteit in de vorm van een syndroom of een diagnose maar om enerzijds een normaal verschijnsel dat in iedere arbeidssituatie optreedt, en enerzijds om een specifieke klacht die de kern uitmaakt van werkgerelateerde psychische problemen zoals overspanning en burnout. Het NWO-PVA-programma richt zich op beide typen vermoeidheid, en op de relatie ertussen.

Het onderzoeksprogramma bestaat uit bijna 40 afzonderlijke (dissertatie)projecten die zijn ondergebracht in vijf onderzoekslijnen:

1 Arbeidspsychologisch en psychofysiologisch onderzoek naar taakverrichting en acute vermoeidheid.

2 Organisatiepsychologisch, klinisch psychologisch, psychofysiologisch en sociaal-psychologich onderzoek naar psychische vermoeidheid als klacht.

3 Epidemiologisch onderzoek naar prevalentie, incidentie, risicogroepen en risicofactoren met betrekking tot psychische vermoeidheid.

4 Bedrijfsgezondheidskundig onderzoek naar diagnostiek, behandeling, begeleiding en reïntegratie van werknemers met psychische vermoeidheidsklachten. 
5 Gezondheidskundig onderzoek naar psychische vermoeidheid in de arbeidssituatie in relatie tot chronische ziektes zoals reuma en diabetes.

In dit themanummer van $G \uplus O$ bieden we een dwarsdoorsnede van onderzoek dat is uitgevoerd binnen de eerste drie onderzoekslijnen. Het nummer wordt geopend met een epidemiologisch artikel van Kant, Jansen, Van Amelsvoort, Mohren en Swaen over burnout in de werkende bevolking. Alhoewel het verschijnsel burnout in talloze studies is onderzocht ontbreekt tot nu toe essentiële epidemiologische kennis over de prevalentie en de incidentie ervan. De Maastrichtse Cohort Studie, waarin ruim 12.000 werknemers gedurende 4,5 jaar zijn gevolgd biedt een uitstekende mogelijkheid om in deze kennisleemte te voorzien. Het artikel van Mommersteeg, Heijnen, Ger Keijsers, Verbraak en Van Doornen gaat op een ander aspect van burnout in dat nog nauwelijks is onderzocht, namelijk eventuele psychofysiologische ontregelingen. Door velen wordt weliswaar aangenomen dat burnout samenhangt met verstoringen van bepaalde psychofysiologische patronen, zoals de afgifte van cortisol in het lichaam, maar het zeer schaarse onderzoek dat hiernaar is verricht spreekt elkaar tegen. Het onderzoek van Mommersteeg c.s. is uniek in zijn soort omdat het betrekking heeft op werknemers die psychotherapeutisch behandeld worden voor burnout-klachten. Het theoretische artikel van Tops, Lorist, Wijers en Meijman is eveneens psychofysiologisch van aard, en koppelt het fenomeen psychische vermoeidheid aan de werking van neurofysiologische en neurobiologische processen in de hersenen. Dit artikel biedt een fris perspectief op psychische vermoeidheid en burnout, waarbij bevindingen uit meerdere wetenschapsgebieden worden geintegreerd. Ten slotte bevat het themanummer twee organisatiepsychologische studies, waarvan er één betrekking heeft op een literatuuronderzoek naar de effecten van zelfsturende teams op psychsich welbevinden /Van Miero, Rutte, Kompier en Dodewaard). Het artikel van De Jonge, Dormann en Van Vegchel, ten slotte, introduceert een nieuw theoretisch model - het zogenoemde Demand-Induced Strain Compensation (DISC)-Model - dat poogt om het optreden van psychische klachten (waaronder vermoeidheid) te verklaren uit een specifieke constellatie van taakeisen en compensatoire hulpbronnen die al dan niet in de arbeidssituatie aanwezig zijn.

We hopen dat deze vijf artikelen, ieder op hun eigen wijze, een indruk geven van het (multidiciplinaire) onderzoek dat binnen het NWO-PVA-programma is verricht naar psychische vermoeidheid in de arbeidssituatie.

\section{Literatuur}

Houtman, I. (red.) (1997). Trends in arbeid en gezondheid 1996. Amsterdam: NIA, TNO. Koningsveld E.A.P., Zwinkels, W.S., Mossink, J.C.M., Thie, X.M. \& Abspoel, M. (2004). Maatschappelijke kosten van arbeidsomstandigheden van werknemers in 2001. Doetinchem: Elsevier.

Meijman, T.F. \& Schaufeli, W.B. (1996). Psychische vermoeidheid en arbeid. De Psycho$\operatorname{loog}, 31,236-242$. 